\title{
THE IMPLEMENTATION OF KURIKULUM TINGKAT SATUAN PENDIDIKAN (KTSP) IN THE TEACHING OF ENGLISH; A DESCRIPTIVE STUDY IN THE TENTH GRADE OF SMA NEGERI 1 NGUNUT, 2013/2014 ACADEMIC YEAR
}

\author{
Anis Azimah \\ English Education Department, IAIN Tulungagung \\ Email: anisazimah@outlook.com
}

\begin{abstract}
The objective of this study is to describe the teachers' perceptions towards the implementation of Kurikulum Tingkat Satuan Penddikan (KTSP) in SMA Negeri 1 Ngunut and also the implementation of Kurikulum Tingkat Satuan Pendidikan (KTSP) in the Teaching of English in the classroom for the tenth grade students of SMA Negeri 1 Ngunut 2013/2014 academic year, including its material, teaching learning activity and the evaluation. Further more, it is also intended to know more about the strengths and the weaknesses of the implementation of Kurikulum Tingkat Satuan Pendidikan (KTSP). In this research, the writer uses a qualitative research. To describe the students' and teachers' perception towards the implementation of Kurikulum Tingkat Satuan Pendidikan (KTSP) in the class, the researcher uses descriptive method. The technique of collecting the data in this research is unobtrusive observation, indepth interviewing, and document analysis. The writer uses guided-interview to support the data. In analyzing the data, the writer uses interactive analysis method by data reduction, data display, and conclusion drawing. After doing observation and interview, the writer can conclude that the teachers have good perception towards the implementation of KTSP in the school and play their role as teachers in the classroom well. The implementation of Kurikulum Tingkat Satuan Pendidikan (KTSP) in the teaching of English at the tenth grade of SMA Negeri 1 Ngunut is well conducted. The teaching-learning activity in the classroom runs well because the teachers always try to encourage the students in teaching-learning process. The material given to the students in teaching-learning activity is appropriate to the KTSP's standard material.
\end{abstract}

\section{Key words: Implementation, Kurikulum Tingkat Satuan Pendidikan (KTSP),}

\section{Received: 23 June, 2016; Accepted: 8 September, 2016}

\section{INTRODUCTION}

There are some important components of education. They are students, teacher, classroom interaction, content of education and the last is education context. The core stone of education is the interactions between the teacher and the students in order to help the students to achieve the goals in education. To hold the interactions, it needs curriculum.

Development and change which happen in Indonesia is one of many aspects which is affected by the change and development of science and technology, also art and culture which happen in the world. Development and change are continuously asking for the revolution of national education system, including the revolution of curriculum, in order to gain a competitive and dynamic society according to the world revolution. The theory of curriculum is a set of related statements that gives meaning to a school's curriculum by appointing up the 
relationships among its elements and by directing its development, its use, and its evaluation. (Beaucamp in Sukmadinata, 1999: 6).

In order to gain a competitive and dynamic society in Indonesia, we need to increase our education quality, which should be done in all aspects which are dealing with education system, including the development of Indonesian human resources. The development of Indonesian human resources are including the morality aspects, behavioral aspects, attitude aspects, knowledge aspects, health aspects, skill aspects, and art aspects. The objective of these aspects development is to increase and develop the students' skill to encounter various problems which may come which is realized through the gaining of students' capability to survive, to be adaptive, and to be successful. Thereby the students will have their strength, independence, and mature character developed by continuous learning and practice. Therefore, the upgrading curriculum based on the world need is very important. Then, the government revises the previous curriculum, namely Competency Based Curriculum (CBC) into Kurikulum Tingkat Satuan Pendidikan (KTSP). "Kurikulum Tingkat Satuan Pendidikan (KTSP) adalah kurikulum operasional yang disusun oleh dan dilaksanakan di masing-masing satuan pendidikan." (Depdiknas, in Mulyasa, 2006: 12). KTSP is an operational curriculum which is arranged and done by each school / educational institution. KTSP is the improvement of $\mathrm{CBC}$ in order to be more familiar to the teacher and the students, to make the national education system become more relevant and more competitive.

From the explanation above, we know that curriculum is very important in teaching learning process. Curriculum will make the teaching-learning process run smoothly if there is a good relation among its components. Therefore, observing the implementation of KTSP is very important. Based on the reason above, the writer is interested in observing the implementation of KTSP in the tenth grade of SMA N 1 Ngunut.

\section{METHOD}

In Oxford dictionary, research is careful study or investigation, especially in order to discover new facts or information. Further, Cholid Narbuko (1999) defines research as "Kegiatan untuk mencari, mencatat, merumuskan, dan menganalisa sampai menyusun laporanya". It is more than to discover, but also to note, formulate, and analyze facts or information. While Nunan (1992: 2) say:

"Research is about inquiry. It has two components: process and product. The process is about an area of inquiry and how it is pursued. The product is the knowledge generated from the process as well as the initial area to be presented. Research is aimed to collect and analyze the data in specific field with the purpose of proving your theory".

Generally, research is systematic and objective study, in order to better understand and develop theory and principle upon an object. Based on the research definition, it can be concluded that there are some important points of research;1) It is an object 2) The method is systematic and objective 3) The objective is to understand better.

As it is done systematically, research has methodology. Methodology is used as the method to do an inquiry. Further, it can be said that methodology is the way someone uses to conduct a research, as it is stated by Cholid narbuko (1999),

"Metodologi penelitian adalah salah satu cabang ilmu pengetahuan yang membicarakan /mempersoalkan mengenai cara melaksanakan penelitian yaitu 
meliputi kegiatan mencatat, merumuskan, menganalisa sampai menyusun laporanya berdasarkan fakta-fakta atau gejala-gejala secara ilmiah"

Based on the phenomena being studied, qualitative research methodology is used in this study. Qualitative methodology refers in the broad sense to research that produce descriptive data: people's own written or spoken words and observable behavior (Bodgan and Taylor, 1984). Researcher in qualitative methodology look at people and setting as a whole not reduces to variables. Researcher interacts with people in a natural setting and unobtrusive manner. When researchers study people qualitatively, they get to know people personally and their daily experience. Researcher tries to get deeply involved in the world of people being studied.

Based on the sources of data, the writer must gain access to the setting or situation. The most generally techniques which are used include observation, interview, collection and review of related document. Wiersma (2000) calls these techniques as an interactive data collection technique, where the researchers are interacting with the subjects who are being studied.

a. Observation

Observation is based on direct experience, so that researcher has to interact with people in a setting directly. Researcher can make a field note based on what they have seen; setting, manner and whatever in accordance with the real situation. Observation can be a way to avoid bias information, because through observation researcher can check the situation directly. Johnson and Christensen (2000) say that, "Observation is important ways to collecting information about people, because people do not always do what they say do".

There are two kinds of observation as Joko Nurkamto quotes from Spradley (1980); non-participant observation and participant observation. This study uses participant observation where the writer involved in setting being studied. The writer will be observing the implementation of Kurikulum Tingkat Satuan Pendidikan (KTSP) at SMA Negeri 1 Ngunut.

b. Interview

Qualitative research gives researcher many chances to talk with people in the research setting. Bodgan and Taylor (1982) as cited in Ely (1991), states that interview is, "...A purposeful conversation usually between two people (but sometimes involved more) that is directed by one in order to get more information"

\section{FINDINGS AND DISCUSSION}

The findings are focused on the teacher's perception toward the implementation of Kurikulum Tingkat Satuan Pendidikan (KTSP), the implementation of KTSP, and the strengths and weaknesses of the implementation of KTSP.

\section{Teacher's perception towards KTSP}

The teacher said that KTSP is a good curriculum, but, as she for one, there are many obstacles in implementing KTSP. One of the obstacles in implementing KTSP is about the amount of students in class. According to the teacher, it should be only about twenty students in a class, but in reality, there are about forty students in a class of SMA Negeri 1 Ngunut. It affects teacher's concentration in teaching them. 
Researcher :"Apa tanggapan Ibu terhadap penerapan KTSP, khususnya dalam pengajaran bahasa Inggris?"

Teacher : "Sebenarnya KTSP itu bagus juga ya, tapi memang banyak kendala disini. Diantaranya itu tadi ya, kan disini guru harus siap ya, harus bisa memepersiapkan segalanya, dan ini menyangkut biaya juga ya, kan biayanya banyak. Sebenarnya untuk di Indonesia itu belum siap ya. Terus, jumlah muridnya juga masih terlalu banyak, kan seharusnya satu kelas itu cuma duapuluh anak. Sebenarnya kalau biayanya juga ada itu bagus."

It seems that the teacher actually does not really understand about the concept of KTSP, but the teacher keeps trying to apply KTSP as optimal as possible. Teacher said that the teaching process should be synchronized with the students' condition, time, and class situation. What the teacher did actually is in line with the concept of KTSP. The concept of KTSP is the teaching learning process should be dealing with students' condition, environment and school condition. So the teacher has done the right procedure in teaching the students.
Researcher : "Apakah Ibu sudah sepenuhnya memahami dan menguasai sistem pengajaran mengunakan KTSP?"
Teacher : "Ya belum sepenuhnya sih."
Researcher : "Bagaimanakah peran guru dalam proses pengajaran menggunakan KTSP? Apakah sudah maksimal?"
Teacher : "Belum, belum maksimal karena kan kadang kita harus menyesuaikan dengan waktu, waktunya harus kita perhitungkan ya, kondisi anak, situasi kelas."

In addition, teacher's appraisal about the implementation of KTSP in her teaching is not something wrong. It is supported by the student's statement in one of the interview with the students.

\begin{tabular}{|c|c|}
\hline Researcher & $\begin{array}{l}\text { : "Bagaimana pendapat Adik tentang penerapan KTSP dalam } \\
\text { pengajaran bahasa Inggris?" }\end{array}$ \\
\hline Student & $\begin{array}{l}\text { "Penerapanya sama saja seperti sebelumnya, cuma materinya sedikit } \\
\text { lebih banyak, terus kayak dipaksa untuk aktif." }\end{array}$ \\
\hline Researcher & $\begin{array}{l}\text { : "Apakah belajar bahasa inggris manjadi lebih mudah atau sukar? } \\
\text { efektif atau tidak?" }\end{array}$ \\
\hline Student & $\begin{array}{l}\text { : "Untuk pengajaranya lebih mudah karena lebih efektif untuk } \\
\text { materinya itu dikejar-kejar, jadi lebih memahami." }\end{array}$ \\
\hline Researcher & :"Bagaimana pengajaran bahasa Inggris di kelas?" \\
\hline Student & $\begin{array}{l}\text { : "Pengajaranya sangat menyenangkan karena ada listeningnya } \\
\text { walaupun susah untuk mengerjakanya tapi asik aja dengar orang } \\
\text { bicara pakai bahasa Ingoris, logat barat gitu"" }\end{array}$ \\
\hline
\end{tabular}

From the citation of interview above, the student has a good response towards the KTSP and its implementation in his school. He also knows that in KTSP, the students are 
encouraged to be active learners. It indicates that he is ready to have teaching-learning process with KTSP.

2. The implementation of KTSP in English teaching in class

Implementation which is meant in this study is observed in the materials given, the teaching learning activity, and the evaluation.

a. The English material given

Based on the KTSP, the materials of English learning teaching activity in Senior High School should fulfill some basic competency for each of language skills. It can be described as follows; taken from PERMEN Nomor 23 Tahun 2006 about Standart Kompetensi Kelulusan (Graduation Competency Standard) and from Pedoman Pengembangan Silabus (Syllabus Development Guidance) for the first grade Senior High School students, the second semester:

1) Mendengarkan

Merespon makna dalam percakapan transaksional (to get things done) dan interpersonal (bersosialisasi) resmi dan tak resmi secara akurat, lancar dan berterima menggunakan ragam bahasa lisan sederhana dalam berbagai konteks kehidupan sehari-hari dan melibatkan tindak tutur: berterima kasih, memuji, mengucapkan selamat, menyatakan rasa terkejut, menyatakan rasa tak percaya, serta menerima undangan, tawaran, dan ajakan.

Merespon makna yang terdapat dalam teks lisan fungsional pendek sederhana (misalnya pengumuman, iklan, undangan dll.).

Merespon makna dalam teks monolog sederhana yang menggunakan ragam bahasa lisan secara akurat, lancar dan berterima dalam konteks kehidupan sehari-hari dalam teks berbentuk; narrative, descriptive, dan news item.

2) Berbicara

Mengungkapkan makna dalam percakapan transaksional (to get things done) dan interpersonal (bersosialisasi) resmi dan tak resmi secara akurat, lancar dan berterima dengan menggunakan ragam bahasa lisan sederhana dalam konteks kehidupan sehari-hari dan melibatkan tindak tutur: berterima kasih, memuji, mengucapkan selamat, menyatakan rasa terkejut, menyatakan rasa tak percaya, serta menerima undangan, tawaran, dan ajakan.

Mengungkapkan makna dalam bentuk teks lisan fungsional pendek (misalnya pengumuman, iklan, undangan dll.).

Mengungkapkan makna dalam teks monolog sederhana dengan menggunakan ragam bahasa lisan secara akurat, lancar dan berterima dalam konteks kehidupan seharihari dalam teks berbentuk: narrative, descriptive, dan news item.

3) Membaca

Merespon makna dalam teks fungsional pendek (misalnya pengumuman, iklan, undangan dll.) resmi dan tak resmi secara akurat, lancar dan berterima yang menggunakan ragam bahasa tulis dalam konteks kehidupan sehari-hari. 
Merespon makna dan langkah-langkah retorika dalam esei sederhana secara akurat, lancar dan berterima dalam konteks kehidupan sehari-hari dan untuk mengakses ilmu pengetahuan dalam teks berbentuk narrative, descriptive, dan news item.

4) Menulis

Mengungkapkan makna dalam bentuk teks tulis fungsional pendek (misalnya pengumuman, iklan, undangan dll.) resmi dan tak resmi secara akurat, lancar dan berterima yang menggunakan ragam bahasa tulis dalam konteks kehidupan seharihari.

Mengungkapkan makna dan langkah retorika dalam esei sederhana secara akurat, lancar dan berterima dalam konteks kehidupan sehari-hari dalam teks berbentuk narrative, descriptive, dan news item.

\section{b. Teaching learning activity}

In teaching learning activity in the class, the teachers usually open the class by greeting, then reviewing some materials from the previous meeting, and continued by the teaching-learning activity. In conducting teaching-learning process, the teachers do not use a certain method, but vary of it. This is in accordance with what is arrowed by KTSP that in learning it is important to create a conducive learning environment by using various methods and media, so that the learners will be able to learn composedly and fun.

Researcher : :Persiapan mengajar apa yang biasa dilakukan sebelum mengajar?"

Teacher : "Ya tergantung apa yang akan saya berikan ke siswa, jadi hari ini saya mau mengajarkan text recount itu ya saya harus, misalnya saya punya media ya, alat-alat mengajar ya saya bawa, apa gambar. Kalau recount itu kan pengalaman pribadi Mbak, misalnya "Spending the holiday in Yogyakarta", misalnya saya punya gambar keraton ya saya bawa. Jadi mereka ya nyambung. Berarti itu kan saya pakai metode dulu. Ya buat dulu mereka tu siap. Ya terus saya tanya-tanya tentang liburan kemarin kemana, ya baru saya berikan recount. Ya misalnya description saya mau misal tentang Blue Whale, ya saya tanya-tanya dulu tentang kehidupan laut atau ikan-ikan, ya "Ikan apa yang menarik bagi kamu?". Ya mereka ada yang menjawab ikan Cupang, ada yang Arwana atau apa gitu, terus saya ke Paus gitu. Ya saya diskripsinya gitu. Saya nyaman koq dengan itu. Kalau sebenarnya KTSP itu gimana prosedurnya, malah saya gak pernah pikir. Iya, malah pakai itu menyenangkan sekali. Anak-anak jadi hidup koq, mereka kan itu, jadi "ini bu-ini bu", saya pakai yang lama lho, ada pre-, whilst- and post-reading. Boleh pakai cara apapun asal mereka aktif. Ya, mereka bisa aktif kalau mereka nyambung”.

Researcher : "Persiapan mengajar apa yang biasa dilakukan sebelum mengajar?"

Teacher : "Yang jelas itu kan harus membuat lesson plan. Memepersiapkan tape recorder. Kalau gak siap nanti kan membuang waktu di kelas, waktunya habis."

Researcher : "Metode apa yang sering digunakan dalam pengajaran KTSP?" 
Teacher : : "Kalau metode macam-macam ya, ada penugasan, diskusi, ceramah ada tapi sedikit, presentasi, anak-anak kan disuruh maju ke depan, misalnya disuruh mendongeng."

During the observation, the writer noticed that the teacher always tried to involve the students actively in teaching learning activity. In most of the time, the teacher initiated an exchange, usually in the form of question or comment. One of the students gave his/her answer to the teacher's question, or it might be answered by all of the members of the class together. Responding to the students' answer, the teacher gave feedback or error treatment; it could be in the form of assessment, correction or comment. In the intervals of teaching, the teacher gave motivation to the students.

Besides that, the teacher also tried to play some roles in the class. Not only as a teacher who helps the students to learn, teacher here also played a part as a guide, a facilitator, a motivator, an evaluator, a mediator and media of learning. Furthermore, teacher is also as a source of learning.

Researcher : "Bagaimanakah posisi guru dalam penyusunan KTSP?"

Teacher : :Guru itu kan tugasnya menyiapkan lesson plan, guru dalam hal ini kan sebagai fasilitator, motivator, evaluator, dsb ya...".

The communication in the class between the teacher and the students are quite interactive. The students confess about the interaction in the class as follows:

Researcher : "Apakah belajar bahasa inggris manjadi lebih mudah atau sukar? efektif atau tidak?"

Student : "Untuk pengajaranya lebih mudah karena lebih efektif untuk materinya itu dikejar-kejar, jadi lebih memahami".

Researcher : "Bagaimana pengajaran bahasa Inggris di kelas?"

Student : "Pengajaranya sangat menyenangkan karena ada listeningnya walaupun susah untuk mengerjakanya tapi asik aja dengar orang bicara pakai bahasa Inggris, logat barat gitu".

Researcher : "Bagaimana pengajaran listening, speaking, reading dan writing? Terpisah atau dipadukan?"

Student : "Untuk pengajaran listening, speaking, reading sama writing itu dipisah-pisah biar muridnya itu gak bingung gitu lho, gak kecampurcampur. Dipisah-pisah jadi Lebih mudah".

Researcher : "Bagaimana materi belajarnya? Bagus atau tidak? Apakah sudah cukup aplikatif (berhubungan dengan kehidupan sehari-hari) atau tidak?"

Student : "Bagus banget Mbak, karena bahasanya kan dalam sehari-hari sangat komunikatif banget. Bisa diterapkan, misalnya ketemu sama orang barat itu butuh bahasa Inggris dan susunan bahasanya bener gitu lho".

Researcher : "Bagaimana peran guru dalam mengajar?"

Student : "Lebih sedikit karena muridnya lebih aktif".

Researcher : "Apa saja kegiatan yang dilakukan di dalam kelas?” 
Student : "Biasanya membahas paket bahasa Inggris, listening, reading, reading comprehension, reading aloud".

Researcher : "Apakah belajar bahasa inggris manjadi lebih mudah atau sukar? efektif atau tidak?"

Students : "Sebenarnya mudah dan menyenangkan dan dalam metode KTSP lebih enak dan santai, jadi lebih efektif".

Researcher : "Apa saja kegiatan yang dilakukan di dalam kelas?"

Student : "Mencatat, listening, ada kegiatan hiburan misal drama dalam bahasa Inggris, speaking, gak ada diskusi, saat ini belum ada presentasi".

Researcher : "Bagaimana pengajaran listening, speaking, reading dan writing? Terpisah atau dipadukan?"

Student : "Terpisah, lebih enak dijadikan satu ya Mbak ya, soale kalau dijadikan satu kan bisa saling terkait gitu lo, jadinya kan bisa, apa, misalnya listening sama speaking kan terkait, reading sama writing kan terkait, gitu".

Researcher : "Bagaimana materi belajarnya? Bagus atau tidak? Apakah sudah cukup aplikatif (berhubungan dengan kehidupan sehari-hari) atau tidak?"

Student : "Materi belajarnya susah mbak, susah diterima. Ya sebagian ada yang berhubungan, sebagian lagi ada yang tidak berhubungan. Iya bermanfaat, soalnya sekarang bahasa Inggris itukan ya bahasa intrenasional, jadi bisa bermanfaat bagi kita, tapi yang memahami, yang gak ya sebel".

Researcher : "Apa saja kegiatan yang dilakukan di dalam kelas?"

Student : "Mencatat, listening, ada kegiatan hiburan misal drama dalam bahasa Inggris, speaking, gak ada diskusi, saat ini belum ada presentasi”.

Based on the observation which has been conducted by the writer, the teacher integrated the four language skills appropriately in each meeting. Listening practice is usually conducted in class using tape recorder. The speaking practice is usually in the form of expressing something or reading a passage in turns. Reading practice can be in the form of reading aloud or reading comprehension. Writing practice can be in the form of task or homework given to the students. In harmony with the concept of KTSP, the teacher also conducted the lesson that stresses on life skill and makes the student become active.

Reseacher : "Bagaimanakah prosedur pengajaran bahasa Inggris dengan KTSP?"

Teacher : :Kalau KTSP itu kan integrated kita tidak bisa memisahkan antara listening, speaking, reading and writing, jadi satu kesatuan".

Researcher : "Bagaimana metode pengajaran untuk setiap skill (listening, speaking, reading, dan writing) dalam KTSP? Apakah secara terpisah atau dipadukan?"

Teacher : "Saya yang sendiri-sendiri, listening, speaking sama reading, writing bisa integrated, tapi kalau listening sendiri-sendiri". 
c. The evaluation

In Kurikulum Tingkat Satuan Pendidikan (KTSP), the teacher should pay attention to three aspects. They are cognitive aspect, psychomotor aspect and affective aspect. The cognitive aspect includes the students' knowledge in language aspect (vocabulary, pronunciation, intonation, etc.) and language skill (listening, speaking, reading and writing). The psychomotor aspect is about the students' physical action in doing something from the teacher during the learning process, while for the affective aspect can be seen from the students' attitude, interest and enthusiasm during the learning process.

\begin{tabular}{|c|c|}
\hline Researcher & : "Nilai psikomotorik dan afektif didapat dari kegiatan seperti apa?" \\
\hline Teacher & $\begin{array}{l}\text { : "Misalnya guru memberi PR, siapa yang mengumpulkanya tepat } \\
\text { waktu, nanti nilainya dapat tambahan, kalau yang telat } \\
\text { mengumpulkan, nilaiya agak kurang, waktu guru menerangkan, } \\
\text { mereka berperan aktif, dan lain-lain ya, itu tadi diantaranya". }\end{array}$ \\
\hline Rese & : "Bagaimanakan sistem evaluasi dalam KTSP?” \\
\hline Teacher & : "Ada tertulis, ada lisan, ya sesuai kebutuhan saja". \\
\hline
\end{tabular}

Evaluation of the cognitive aspect can be taken from the task given by the teacher, daily test and final test. In addition, there are also remedial test for the students who haven't passed the minimal score (batas tuntas) of a basic competency

3. The strengths and the weaknesses of the implementation of KTSP in SMA Negeri 1 Ngunut

From the research conducted by the writer, there are some strengths and weaknesses in the implementation of KTSP in SMA Negeri 1 Ngunut.

a. The strengths

1) The students become more active and enthusiastic

Since the students are the subject of teaching learning process, they should be more active in looking for the source of learning and also in the teaching learning activity, not only passive. This is in harmony with the teacher's statement:

"Kalau menurut saya ya dalam memberikan pelajaran ke siswa, siswa diharapkan bisa lebih aktif dengan memakai KTSP tersebut..."

follows:

Also, as quoted by the writer from her interview with teacher, as

Researcher : "Bagaimana peran siswa dalam KTSP?"

Teacher : "Mereka harus berperan aktif, tidak hanya pasif. Makanya kalau saya memberi tugas itu ya, mereka kan jadi rebutan ya, karena mereka itu tahu kalau maju dapat tambahan nilai”.

The activeness of the students is not only stated by the teachers, but also by the student, as stated in the interview as follows:

Researcher : "Bagaimana pendapat Adik tentang penerapan KTSP dalam pengajaran bahasa Inggris?" 
Student $\quad$ : "Penerapanya sama saja seperti sebelumnya, cuma materinya sedikit lebih banyak, terus kayak dipaksa untuk aktif'.

2) Stressing more on life skill

By stressing more on life skill, students will be supplied more on life skill and be more ready to prepare their future. It is relevant to the aim of KTSP that is to create a conducive climate for the implementation of education that is oriented to life skill and academic. This is appropriate to the teacher's explanation as quoted by the writer in her interview;

"Kalau menurut saya ya dalam memberikan pelajaran ke siswa, siswa diharapkan bisa lebih aktif dengan memakai KTSP tersebut, karena memang apa ya, disitu kita diharapkan bisa memberi contoh pada siswa. Misalnya siswa diberi satu genre procedure ya didalam kelas itu siswa harus benar-benar misalnya membuat ini, bagaimana cara membuat pesawat terbang bisa mengudara, perlu didemonsrasikan. Sebenarnya juga apa ya, semacam challenging, menantang ya buat anak-anak. Ini lho mbak, mereka jadi tahu bagaimana mereka menulis apa yang dia pikirkan dengan cara yang benar, jadi misalnya gini ya Mbak ya, untuk menceritakan pengalaman pribadi, kalau dulu kan nulis aja sak karepe, terserah mereka. Kalau sekarang kan gak, kalau untuk menceitakan pengalaman pribadi itu pakai recount, recount tu generic structure-nya gini. Jadi mereka bisa menuliskanya secara urut, ya itu mungkin kelebihanya. Misalnya mau menceritakan legenda itu anak-anak pakai narrative, yg pertama ada orientation, problem, kemudian resolution. Jadi mereka sekarang bisa how to write, bagaimana menulis dengan benar dan bagus".

Furthermore, teacher explained that KTSP material is applicable and can make the students become independent, as stated by the teacher as follows:

"Kalau kelebihanya murid-murid bisa menuangkan pikiranya dalam form atau bentuk yang benar. Maka sekarang ini dengan diberikan pelajaran review, mereka diminta mengevaluasi karya seni, mereka bisa sekarang, karena ada genre review, jadi misalnya anak nonton film mereka bisa evaluasi pemainya, jalan ceritanya, penulisnya. Dulu mungkin bisa tapi gak seurut sekarang. Jadi sekarang mereka kalau jadi wartawan reporter itu bisa ada bekal dari situ. Apa sebenarnya tujuan pemerintah itu ya. Jadi mereka bisa mandiri, jadi mereka begitu lepas dari sekolahan, misal yang berbakat jadi presenter itu bisa, jadi mereka bisa dengan genre report juga diskripsi itu".

3) The material given is applicable

The material given to the students according to the KTSP should be related to their environment, to make the learning activity become more effective. Based on the explanation given by the teacher, SMA Negeri 1 Ngunut has been synchronizing their learning material to the students, school, and environment condition; as stated by the teacher as follows:

"KTSP silabusnya disesuaikan kondisi anak, kondisi sekolah, tapi kalau dulu kan guru mengajar itu sudah ada kurikulumnya, jadi seluruh indonesia itu sama". 
The material which is arranged by teacher and schools themselves is appropriate with the students' need. This statement is in line with the teacher statement as follows:
Researcher : "Materi yang dibuat sendiri oleh sekolah tersebut apakah sudah sesuai dengan kebutuhan murid?"
Teacher : "Saya kira sudah ya Mbak ya".

The appropriateness and the usefulness of the material given by the teacher are not only stated by the teachers, but also by the student, as stated in the interview as follows:

Researcher : "Bagaimana materi belajarnya? Bagus atau tidak? Apakah sudah cukup aplikatif (berhubungan dengan kehidupan sehari-hari) atau tidak?"

Student : "Bagus banget Mbak, karena bahasanya kan dalam sehari-hari sangat komunikatif banget. Bisa diterapkan, misalnya ketemu sama orang barat itu butuh bahasa".

4) The students feel that learning English is fun and easy

The students feel that learning English is fun and easy. The students' positive feeling and response about learning English will help them study better than before, because their positive feeling and response can motivate them to learn optimally. This is in line with the students' statements as follows:

Researcher : "Apakah belajar bahasa inggris manjadi lebih mudah atau sukar? efektif atau tidak?"

Student : : "Untuk pengajaranya lebih mudah dan lebih efektif untuk materinya itu dikejar-kejar, jadi lebih memahami".

Researcher : "Bagaimana pengajaran bahasa Inggris di kelas?

Student : Pengajaranya sangat menyenangkan karena ada listeningnya walaupun susah untuk mengerjakanya tapi asik aja dengar orang bicara pakai bahasa Inggris, logat barat gitu”.

5) The material is more numerous

The material given to the students in KTSP is more numerous. It makes the students have to study harder and have to study more frequently than before. It is good to make the student study as frequently as possible. This statement is stated in the interview as follows:

Researcher : "Apa perbedaanya dengan pengajaran memakai KBK?"

Student : "Perbedaanya itu gak beda-beda banget ya Mbak ya, cuma sedikit banget tapi menurutku materinya lebih banyak, yang KTSP itu kalau gak salah ya, materi kelas dua masuk materi kelas satu ,jadi lebih padat".

Researcher : "Lebih seneng yang mana?"

Student : "Lebih padat karena untuk nantinya kedepanya gak susah-susah banget ngulangnya". 


\section{The Weaknesses}

1) Lack of socialization

The teachers feel that KTSP is good actually, but for they did not get maximum socialization, explanation, and supervision; it makes them become confuse and it become obstacles for them in implementing KTSP optimally. This is in line with the teacher statement as follows:

$\begin{array}{ll}\text { Researcher } & \begin{array}{l}\text { : "Apakah Ibu sudah sepenuhnya memahami dan menguasai sistem } \\ \text { pengajaran mengunakan KTSP?" }\end{array} \\ \text { Teacher } & \text { "Ya belum sepenuhnya sih". }\end{array}$

2) The amount of the students in the class is not appropriate with the teachers' capabilities

The amount of students are there in a class affects the teacher's distribution of attention and treatment to each of the students. Too much students are there in a class will make the teacher's attention and treatment to each of the students become not optimal. The more the teacher handles class, the more duty that the teacher should do, and it affect the teacher optimality in doing his duty. This is as stated by the teacher as follows:

"...Kelemahanya itu, pekerjaan guru menjadi banyak banget, untuk memberi penilaian yangg ideal itu sulit ya. Idealnya guru mengajar tiga sampai empat kelas saja".

3) The lack of learning cost

The implementation of KTSP needs learning cost to support its implementation. The teacher feels that the learning cost is also an obstacle to implement KTSP in English learning teaching, optimally.

"Sebenarnya KTSP itu bagus juga ya, tapi memang banyak kendala disini. Diantaranya itu tadi ya, kan disini guru harus siap ya, harus bisa memepersiapkan segalanya, dan ini menyangkut biaya juga ya, kan biayanya banyak...Sebenarnya kalau biayanya juga ada itu bagus".

4) The minimum supervision from the teacher sometimes makes the students become confuse 
KTSP stresses on the student; it is more student-centered rather than teachercentered. Students should be active for themselves; it makes the students sometimes become confused, especially for the passive students, because teacher here is more as the facilitator who facilitates the students learning process rather than gives and explains everything that students do not know yet. This as stated by the student in the interview as follows:

“...kalau gak mengikuti itu benar-benar ketinggalan jadi gak ngerti, gak aktif karena guru kan gak aktif $100 \%$, paling cuma $25 \%$ cuma menjelaskan sedikit yang benarbenar kurang..."

\section{5) The students' lack of vocabulary}

The previous curriculum's (CBC) material of study is thematic, but KTSP's material of study is according to each teacher learning sources. The teacher feels that KTSP learning sources she gave to the students makes the students vocabulary become limited. It is because the government does not give any direction or instruction about what theme should be taught. The teacher become confuse about what text should be given to the students. It is as the teacher said as follows.

"...Menurut saya Mbak, anak-anak itu vocab-nya jadi kurang..."

6) Less of time allotment to learn optimally for the students and teacher felt that making syllabus is not easy

Teacher said that the time allotment to study in school is not enough to make the students really mastering all the material that given to them. Also teacher felt that making syllabus by them selves is not easy. They have to considering all the students condition.

Researcher : "Apakah ada kendala dalam penerapan pengajaran bahasa Inggris menggunakan KTSP? Apakah kendalanya?"

Teacher : "Mestinya kebutuhan murid, bahasa kan luas, walaupun guru itu memberi materi yang banyak, mereka kadang itu kurang waktunya. Ngajar bahasa inggris itu kan kendalanya di waktunya. Satu kelas empat kali, satu pertemuan kan 45 menit untuk menguasai keempat skill itu kurang sebenernya. Penyusunan silabus, jadi guru harus menyiapkan materi yang sesuai dengan kondisi anak, itu kan sulit ya, biaya juga..."

\section{CONCLUSION}

Based on the research findings, it is revealed that the implementation of Kurikulum Tingkat Satuan Pendidikan (KTSP) in the teaching of English at the tenth grade students of SMA Negeri 1 Ngunut, is done appropriately. Teachers do the procedure of KTSP perfectly, knew their roles, and knew the students' roles, give appropriate material to the students, and give the appropriate evaluation which is appropriate to KTSP system. At the implementation of KTSP in class, the researcher also discovers some weaknesses and strengths. In general, teachers' perception and understanding towards KTSP determine their action in implementing it. 
Teachers' perceptions towards KTSP are appropriate, although sometimes teachers are still confused about KTSP. They say that KTSP is still new and they are still learning how to do it properly. From the observation, the writer finds that they try to do their duty well.

The implementation of KTSP which is done by the teachers during the teachinglearning process is appropriate to the form of KTSP implementation procedure, though the teacher say that they do not really understand about KTSP implementation procedure. The teachers do their duty to make the students learn effectively and they also teach the students in a good procedure. The steps to make the students' language skill develop significantly have been done by the teacher impartially; it means that the teachers use integrated method to develop the students' language skill. It means that they have to do their duty as the motivator to encourage their students to be more active.

Seen from the material used in KTSP, the material which given to the students is appropriate, because the material is based on the students, school, and environment condition. It means that the material given is appropriate to the KTSP aims.

The writer concludes that the teachers are good facilitators though they are not only as facilitators. They try to make their students more active in learning process; it means that they are also good motivators in class. Their concepts to apply student-centered method are appropriate with the KTSP learning purpose that is to make the students learn as much as they can.

The writer concludes that the students here are the subjects; they are ones who have to learn and do everything to enlarge and enhance their knowledge and skills, though many of them are still passive. In general, the students need more support and motivation from the teacher to make them become actively involved in learning process.

From the procedure of evaluation in KTSP, the evaluation which has been done by the teachers is appropriate. Teachers use two forms of evaluation, written and spoken. It is collected through process approach and learning outcomes by collecting students' portfolio, performance, and pen test. Besides, teachers conduct remedial test as an effort to increase students' mark.

From the explanation above, it can be concluded that there are some strengths and some weaknesses at the implementation of KTSP in SMA Negeri 1 Ngunut. The first strength is every teaching step has been done by the teacher. It could be seen from the observations which have been done. They are Building Knowledge of Field, Modeling of the Text, Joint Construction and Independent Construction. The four steps are the procedural steps which are suggested in KTSP. So, SMA Negeri 1 Ngunut has a good procedural step which is appropriate with KTSP.

The second, the teachers apply an interesting system to attract students attention and activity, the system is reward. It could be seen from the observation that the system could increase students' attention and activity to follow the teaching learning process effectively. In this case, students were psychologically and physically involved in learning process. They become more active and attentive at the learning process.

On the other hand, the implementation of KTSP in SMA Negeri 1 Ngunut also has some weaknesses. The first weakness is the teachers have problems with the time management, because teachers have to prepare everything and do everything perfectly, they feel that they have too much work to do. They become pessimistic that they could not be an ideal teacher. 
The second weakness is teachers also feel that the students' vocabulary do not improve properly. It is because the material given is not thematic. The teachers say that thematic material can enrich students' vocabulary.

The third weakness is the number of the students in class is still too large. Ideally, the number of students in a class should be not more than twenty, but SMA Negeri 1 Ngunut is characterized by forty students in every class. The teachers say that the numbers of students affect their distribution of attention to them.

The forth weakness is the teachers sometimes become confused about what material should be given to their students, because the National Examination is still held by the central government, they said that it should be held by the school itself, because they worry if the examination material is not in line with what they have taught to their students.

Every curriculum has its own strengths and weaknesses. The main point is how to make curriculum become appropriate to the society development. Curriculum should be dynamic, should be in line with the change of society, time, and the development of science and technology. It is in line with Soetopo's and Soemanto's opinion which is stated in Mulyasa (2006:114), that there are some basic principles in developing curriculum to make the curriculum appropriate with the school, students, parents, society, and government expectation. They should be relevant, effective, and efficient, flexible and continuous.

\section{REFERENCES}

Bodgan, Robert C. and Biklen, Sari Knopp. 1982. Qualitative Research for Education: An Introduction to Theory and Methods. Boston: Allyn and Bacon.

BSPN. 2006. Panduan Penyusunan Kurikulim Tingkat Satuan Pendidikan Jenjang Pendidikan Dasar dan Menengah. Jakarta.

Ely, Margot. 1991. Doing Qualitative Research: Circles within C. London; New York: Falmer Press.

Hamalik, Oemar. 2001. Kurikulum dan Pembelajaran: Edisi I. Jakarta: Bumi Aksara.

Johnson, Burke and Christensen, Larry. 2000. Educational Research. Boston: Allyn \& Bacon. Joko Nurkamto. 2002. Konsep dan Karakteristik Penelitian Kualitatif.

Moleong, Lexy J. 2000. Metodologi Penelitian Kualitatif. Bandung: PT Remaja Rosdakarya.

Mulyasa, E. 2006. Kurikulum Tingkat Satuan Pendidikan. Bandung: Remaja Rosdakarya.

Narbuko, Cholid dan Ahmadi, Abu. 1999. Metode Penelitian. Jakarta: Bumi Aksara.

Nasution. 1999. Asas-Asas Kurikulum. Jakarta: Bumi Aksara.

Nunan, David. 1998. Designing Task for the Communicative Classroom. Cambridge: Cambridge University Press.

Nunan, David and Lamb. 1996. The Self-Directed Teacher: Managing the Learning Process. Cambridge: Cambridge University Press.

Spradley, James P.1980. Participant Observation. New York: Holth, Rinehart and Winston.

Sukmadinata, Nana S. 1999. PengembanganKurikulum: Teori dan Praktik. Bandung: Remaja Rosdakarya.

Wiersma, William. 2000. Research Methods in Education. Boston: Allyn \& Bacon 
JARES, Vol. 1 No. 2 September, 2016; p-ISSN: 2502-826X; e-ISSN: 2503-1163

Copyrights@ Balitar Islamic University, Blitar, Indonesia; Http://jares.unisbablitar.ejournal.web.id

Citation: Azimah, Anis . 2016. The Implementation Of Kurikulum Tingkat Satuan Pendidikan (Ktsp) In The

Teaching Of English; A Descriptive Study In The Tenth Grade Of Sma Negeri 1 Ngunut, 2013/2014 Academic Year. JARES, (2016), 1(2): 17-32 